\title{
Global Economic Wood Supply and Demand: The Opportunity ${ }^{1}$
}

\author{
by
}

\author{
David W.K. Boulter ${ }^{2}$
}

\begin{abstract}
World supplies of industrial wood on a sustainable basis are estimated to be adequate to meet future demand to the year 2000 without effecting real price changes. A degree of uncertainty with respect to supply appears around 2025 by reason of demographic pressures on the indigenous (largely tropical) forests in many of the developing countries in the southern hemispere.

Emerging global trends for the supply of and demand for industrial roundwood suggest a shift in the production, consumption and trade in forest products. Such a shift is predicated on a number of supply and demand factors. The key demand factor is the slowing down of population and economic growth in the developed countries accompanied by a greater application of technology in wood processing and/or new products. The key supply factor is the rate of establishment of plantation of fast-growing species in the tropical and sub-tropical regions.

The notion of scarcity, as manifest in the forester's vision of increased timber production goals, will have to be tempered with the reality that market prices in real terms for the major categories of forest products have not materially increased and are unlikely to do so in the foreseeable future.

These potential developments suggest that Canada's comparative advantage based on old-growth stocks of timber will be diminished and future gains in trade will for the most part be based on new products/processes that in turn will call for a more dynamic approach to market development than that characterized by passive exploitation of a fortuitous endowment of natural resources.
\end{abstract}

\section{Résumé}

Les approvisionnements mondiaux en bois industriel selon une base de rendement soutenu sont estimés être en mesure de répondre adéquatement à la demande en l'an 2000 sans forcer de changements de prix réels. Un certain degré d'incertitude relativement à l'approvisionnement apparaît vers 2025 par suite de pressions démographiques sur les forêts indigènes (en majorité tropicales) dans plusieurs des pays en voie de développement dans I'hémisphère sud.

Les tendances globales observées pour l'offre et la demande de bois brut industriel laissent suggérer un déplacement de la production, de la consommation et du commerce des produits forestiers. Un tel changement s'appuie sur un certain nombre de facteurs effectant l'offre et la demande. Le facteur clé de la demande est la réduction de la croissance de la population et de l'économie dans les pays développés, accompagnée par une grande utilisation de la technologie dans la transformation du bois ou encore dans de nouveaux produits. Le facteur clé de l'offre est constitué par le taux de mise en place de plantations constituées d'essences à croissance rapide dans les régions tropicales et sub-tropicales.

La notion de pénurie, telle que manifestée dans la vision du forestier relativement aux objectifs d'accroîssement de la production de matière ligneuse, devra aussi être moduler avec la réalité qui fera que les prix du marché en terme réel pour les principales catégories de produits forestiers n'auront pas augmenter essentiellement et sont fort peu probablement sujets à le faire dans un avenir prévisible.

Ces développements potentiels laissent suggérer que l'avantage comparatif du Canada basé sur le stock de bois issu des forêts surannées diminuera et que les gains à venir dans le commerce international seront pour la majeure partie issus de nouveaux produits ou encore de nouveaux procédés qui en retour, feront appel à une approche encore plus dynamique du développement de marché que ce qui est caractérisé par une exploitation passive d'un filon fortuit de ressources naturelles.

\section{Introduction}

The theme of this meeting, "Reconciling Vision With Reality", is timely given the increased uncertainties of the future direction of the global economy. The notion of sustainable development has entered the lexicon of the day as popularized by the Brundtland Commission and has revived old anxieties about scarcity. The Commission is mostly concerned about the environment, but as Scott and Pearse (1989) point out, an important element in it is fear about future

\footnotetext{
'Paper given as part of the panel on Economic Wood Supply at the CIF Annual Meeting at Kananaskis Village, Alberta on October 17, 1989.

${ }^{2}$ Chief, Forest Sector Analysis, Economics Branch, Forestry Canada.
}

supplies of natural resources and their sustainable exploitation. The rates of deforestation of the tropical rain forests, global warming, etc., that are increasingly receiving media attention do little to abate such anxieties. In Canada where natural resources figure prominently in our national economy, global forces of supply and demand are uppermost in our considerations of future economic growth and overall well-being. It is difficult to dispel such fears despite the empirical evidence to the contrary. I am tempted to subtitle the conferences theme on global wood supply as "Reconciling the forester's vision of scarcity with the reality of glut". I have earlier reviewed global supply - demand for industrial roundwood and fuelwood and am quite optimistic for the former and 
acknowledge that a crisis condition is at hand for the latter in developing countries (Boulter 1986).

The global forest area comprises more than 4 billion hectares or about one-third of the world's land area. The annual harvest of wood from this forest is approximately 3 billion $\mathrm{m}^{3}$, of which slightly more than one-half is consumed for fuelwood. The demand for fuelwood is largely driven by population growth which in many developing countries will result in an even worse supply situation. It has been estimated that the annual minimum need for fuelwood by the year 2000 will be 2.6 billion $\mathrm{m}^{3}$ while the supply capacity is estimated to be 1.5 billion $\mathrm{m}^{3}$ (Arnold and Mhzava 1985). In contrast, the developed countries, with one-quarter of the world's population, account for more than $80 \%$ of world trade in forest products. Such production, consumption and trade have been largely based on natural temperate forests predominately characterized by softwood species. These forests are coming under increasing pressure of a nonindustrial kind, namely the satisfaction of recreational and environmental demands. Given the rapid increases in per capita income and increased leisure time, the growth in demand for such non-market activities has been much greater than for commercial forest products.

However, there are signs that the global forest and the industrial activities thereon may be in the initial stages of transition. This transition is generally one of a small but perceptible shift from relying on natural old growth forests (largely softwoods) to second growth forests and man-made plantations for future industrial woods supplies. Accompanying this reduction of old growth stocks is an expectation of rising real prices for both industrial wood and forest products. Such an expectation may not materialize, at least by the year 2000 and beyond, if both technology and newly emerging competitors have a material effect on incremental requirements.

\section{Patterns of Future Supply and Demand}

As in the past the rate of growth of forest products consumption will be strongly related to the growth of the world's economies. Unlike the past, however, the rate of growth will probably be greatest in the developing countries, especially after the year 2000. A strong possibility exists that the historical trade flows may actually change direction.

The general type of analysis in forecasting future patterns of growth has been to forecast future supply and demand independently, ignore price and, if not, to assume rising real prices which in turn would elicit the necessary investments in both forests and capital plant to increase future supplies. The element missing in these analyses was the role of technology - its impact on wood extraction, wood processing and in end-uses. The main result of not formally addressing this difficult factor is to generally underestimate supply, overestimate demand and to pay little attention to the trend of real prices of forest products.

The supply/demand "gaps" of past forecasts did not materialize, nor did rising real prices which were implicitly supposed to close such gaps. To a very large extent, liberalization of trade, particularly in the post-war era, mitigated these potentially dire regional consequences. The globe was truly beginning to shrink.

A brief discussion of the background to the demand forecasts in Table 1 below is necessary to place them in some context. The world's population is expected to rise from 4.4 billion in 1980 to about 6.3 billion by the year 2000. Despite
Table 1. Forecasts of industrial roundwood demand to 2000

\begin{tabular}{|c|c|c|c|}
\hline Organization & $\begin{array}{l}\text { Year } \\
\text { made }\end{array}$ & $\begin{array}{c}\text { Forecast } \\
\text { volume } \\
\text { (billion } \mathrm{m}^{3} \text { ) }\end{array}$ & $\begin{array}{c}\text { Implicit } \\
\text { growth rate } \\
\text { (\% year) }\end{array}$ \\
\hline FAO & 1988 & 2.1 & 2.3 \\
\hline \multirow[t]{2}{*}{ FAO } & 1982 (high) & 2.6 & 3.53 \\
\hline & (low) & 2.3 & 2.89 \\
\hline $\begin{array}{l}\text { FAO - industry } \\
\text { working party }\end{array}$ & 1979 & 1.8 & 1.64 \\
\hline $\mathrm{SRI}^{1}$ & 1979 & 1.9 & 1.92 \\
\hline
\end{tabular}

${ }^{1}$ Stanford Research Institute

this apparently large increase, the world's population has been slowing from about $1.78 \%$ in the 1980 's to $1.7 \%$ in the year 2000 , with a further slowing down to $1.3 \%$ expected in the period to the year 2025. What is important, however, is rates of growth by the year 2000 will be less in the developed regions of the world than in the developing regions (approximately $0.5 \%$ and $2 \%$ respectively). Additionally, growth in consumption of forest products appears to be diminishing with increasing per capita income in developed economies for a variety of reasons. On the other hand, it is difficult to envisage that the per capita income/consumption path will be dramatically different for developing countries over the long term.

In terms of wood utilization/processing, the increasing use of reconstituted wood products will probably continue to make inroads on the use of solid wood products, with a consequent greater utilization of wood residues. This will lessen the demand for the size and quality of industrial roundwood Similarly, the increased use of wastepaper in this decade will most likely continue with the consequent reduction in demand for pulpwood.

The proportions of industrial roundwood going to the various industries in the forest sector is largely dependent on the relative growth in consumption of their products. The pulp and paper industry is forecast to grow $3.4 \%$ per year, lumber at about $1.9 \%$ and wood-based panels at $4.4 \%$ to the year 2000 (FA0 1988). It should be noted that the estimate for lumber is considerably greater than others in recent years that average about $1 \%$ or less. The growth rate in softwood consumption over the $1960-80$ period was $2.75 \%$ per year while that for hardwoods was $3.5 \%$. This divergent growth rate can be expected to grow (see Fig. 1). These varying forecasts yield, however, a relatively narrow range of roundwood requirements by the year 2000 of $1.8-2.1$ billion $\mathrm{m}^{3}$.

The variance of these forecasts over the past 10 years is evident yet there appears to be somewhat of a downward trend for roundwood requirements. To a considerable extent, these lessened requirements are the result of supply extending (use of smaller logs and less preferred species) and wood-saving (higher recovery factors and use of wastepaper) technologies. Further, the net effect of these applications of technology is that real prices of industrial roundwood exhibit a largely flat trend line over time (Sedjo and Lyon 1986). The same is generally true for forest products worldwide, especially the commodity grades of both solid wood and fibre products (see Figures 2-5 below). Unfortunately, these aspects have not been the object of much empirical analysis and are difficult to measure, much less forecast. Yet it may also be the main reason why studies over the past three decades have tended to underestimate supply and overestimate demand. 


\section{Roundwood Production}

Production Shares

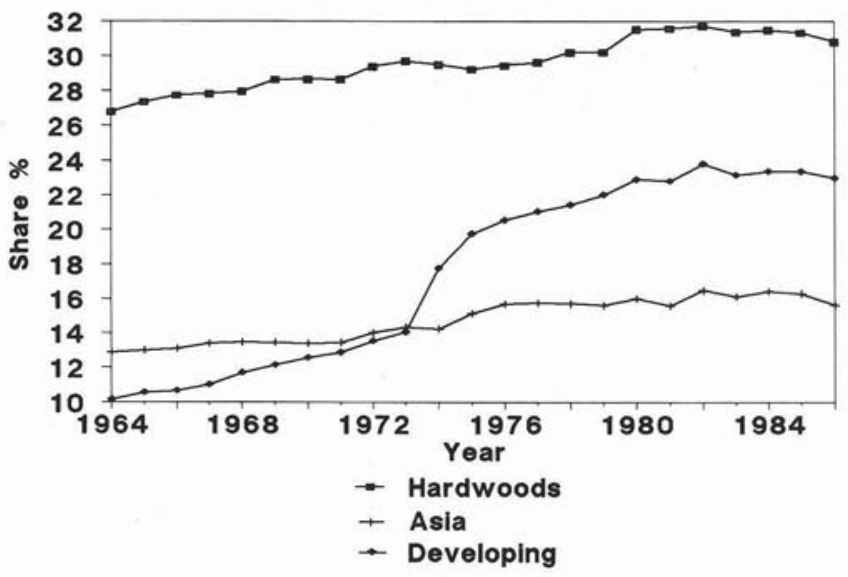

Figure 1. Roundwood production - production shares.

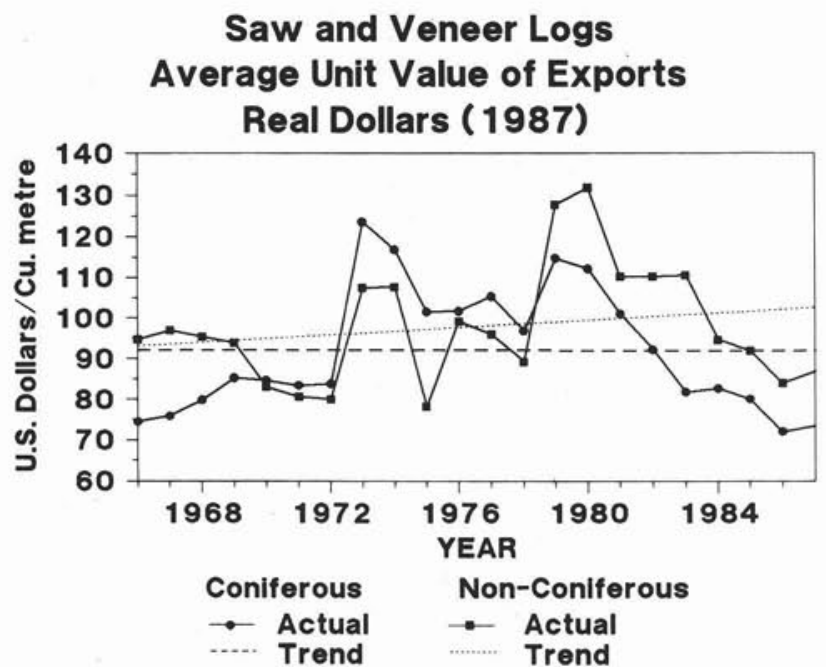

Figure 2. Saw and veneer logs - average unit value of exports, real dollars (1987).

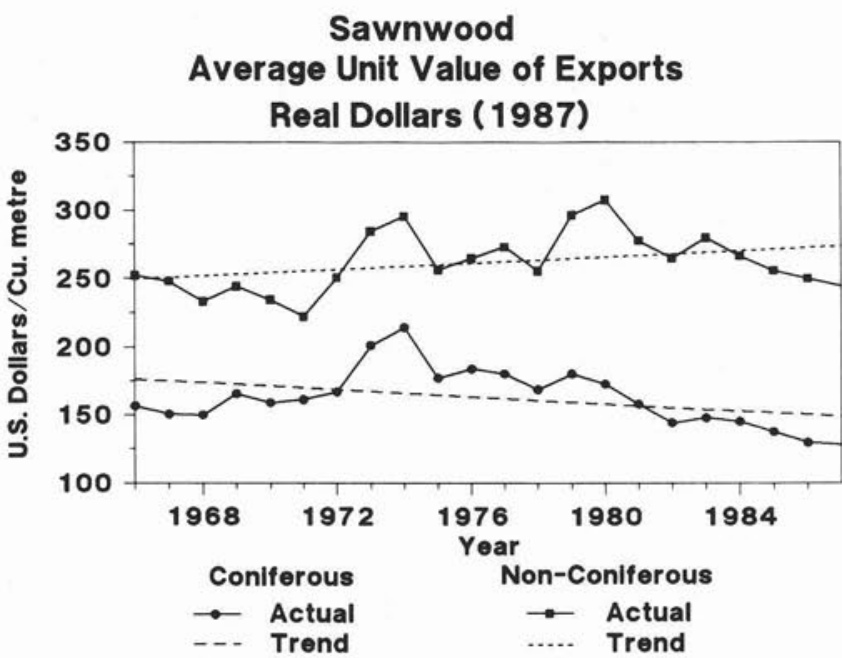

Figure 3. Sawnwood - average unit value of exports real dollars (1987).
Wood based Panels and Plywood

Average Unit Value of Exports

Real Dollars (1987)

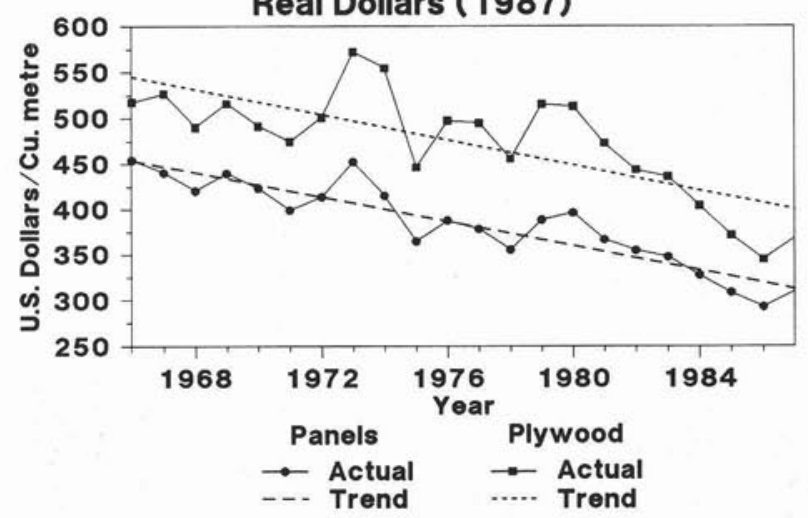

Figure 4. Wood-based panels and plywood - average unit value of exports, real dollars (1987).

\section{Wood Pulp and Paper \& Paperboard Average Unit Value of Exports Real Dollars (1987)}

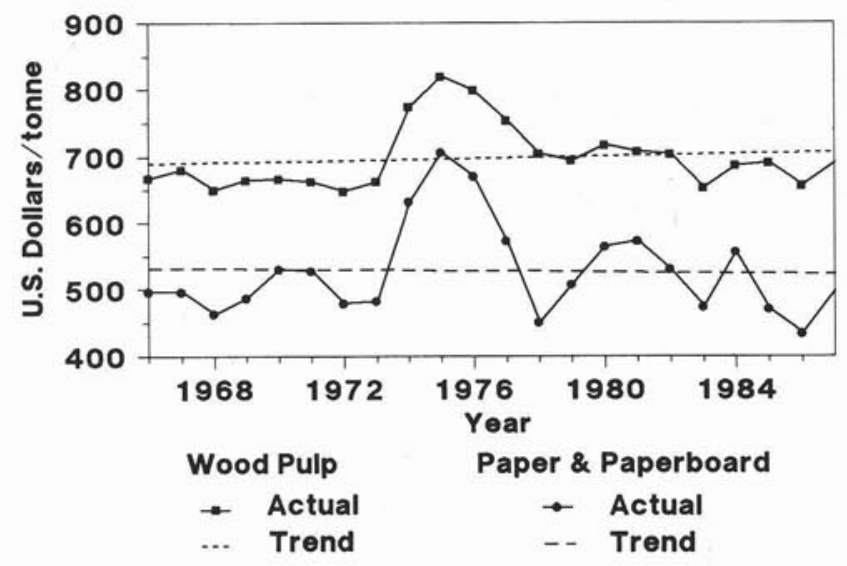

Figure 5. Wood pulp and paper and paperboard - average unit value of exports, real dollars (1987).

Although the major factors determining future wood supply are well-known, forecasts of the future supply remain speculative because the information base is poor. Reliable information on forest inventories and management does not exist for major areas of the globe. However, past experience suggests a rough parallel to the exploration and development in the mining sector, i.e., rising prices and market activity tend to elicit fairly elastic responses in supply.

World supplies of industrial wood on a sustainable basis are estimated to be 2.6 billion $\mathrm{m}^{3}$ per year. Assuming a lower forecast of 1.8 billion $\mathrm{m}^{3}$ for the year 2000 and a growth rate of $1.0-1.5 \%$ to the year 2030 , industrial wood requirements would be 2.4-2.8 billion $\mathrm{m}^{3}$ per year. The lower demand would appear to be satisfied while the higher one could theoretically at least, be met through an increase in the establishment of plantations in the tropical and subtropical regions. Both softwoods (largely several species of pine) and hardwoods (mostly a few species of Eucalyptus and Gmelina) have been used with considerable success. The supply of industrial roundwood from these plantations is expected to increase tenfold in the period $1975-2000$, ie., 150 million $\mathrm{m}^{3}$ or nearly 
$10 \%$ of the low forecast for global demand. Latin America will account for about two-thirds of the tropical countries' supply of such wood, more than $60 \%$ of which will be coniferous species. In the tropics these plantations are expected to increase from 5 million to over 16 million hectares by the year 2000 (FAO 1982). The biological potential in Latin America alone has been estimated at 30 million hectares (McGaughey \& Gregerson 1983).

A note of caution regarding the future performance of fast growing plantations is that the "learning" curve for the successful establishment of a number of species/locations may be in the order of 15 years or so. Nevertheless, the potential to respond to forecasted shortfalls should be apparent. This also suggests that a changing pattern of production, consumption and trade in favour of developing countries may only be clearly established beyond the year 2000 . The pattern will be characterized by a growing net trade deficit in the developed countries for both industrial roundwood and processed wood products accompanied by a dramatic increase in the processing of both indigenous and exotic species in the developing countries. Trade in industrial roundwood (mainly saw and peeler/veneer logs) has generally diminished, at least in a global sense, as an increasing number of developing countries have taken a variety of measures to secure further processing of these natural resources as part of their national economic development policy.

Developments in the forest sector in the Asia-Pacific region, especially SE Asia, may best illustrate this changing pattern.

\section{Supply-Demand Prospects in the Asia-Pacific Region}

A recent study by the Asian Development Bank (ADB) forms the basis of most of the following discussion on future supply-demand prospects for forest products in the AsiaPacific region. It is based on somewhat different data sources and projection methodology and therefore not strictly comparable to the global projections discussed in the preceding section. The projections for regional demand found in Table 2 below are also the median of a number of scenarios and therefore indicative in nature. The intent is to examine demand prospects for the three major groups of forest products in general and to note where their projected performance differs from global trends.

The region has been and remains the major exporter of tropical hardwood saw and veneer logs both within and outside the region. However, recent policy changes in the major log-exporting countries have dramatically curtailed the export of unprocessed logs and the consequent adjustment in the geographical pattern of production and trade for primary forest products is still being made.

Over the past two decades the region has become the largest exporter of hardwood sawnwood on world-wide markets and especially since 1980 by reason of increasing restrictions on log exports. This situation is likely to change, however, as the growth in demand within the region is expected to absorb this current net trade early in the next decade, if not sooner, and the region may even become a net importer of sawnwood by the end of the century. Only Indonesia is likely to have any margin for expansion of exports both within and outside the region. Table 2 summarizes future prospects in production, consumption and trade for the region to the year 2005 .

The growth in production and exports of wood-based panels since the late 1960s has been phenomenal. Among the countries that exhibited such growth, namely Indonesia, the Philippines, the Republic of Korea (ROK) and Malaysia, only

Table 2. Current and projected production, consumption and net trade for forest products in the Asia Pacific region to 2005

\begin{tabular}{|c|c|c|c|c|c|}
\hline & Year & 1980 & 1990 & 2000 & 2005 \\
\hline Product & \multicolumn{5}{|c|}{ ('000 m3) } \\
\hline Sawnwood & $\begin{array}{l}\text { Supply } \\
\text { Demand } \\
\text { Balance }\end{array}$ & $\begin{array}{r}49435 \\
43302 \\
6133\end{array}$ & $\begin{array}{r}55807 \\
54319 \\
1488\end{array}$ & $\begin{array}{r}61791 \\
67288 \\
-5498\end{array}$ & $\begin{array}{r}65340 \\
75043 \\
-9703\end{array}$ \\
\hline Plywood & $\begin{array}{l}\text { Supply } \\
\text { Demand } \\
\text { Balance }\end{array}$ & $\begin{array}{l}7385 \\
3997 \\
3388\end{array}$ & $\begin{array}{r}11781 \\
7320 \\
4460\end{array}$ & $\begin{array}{r}14097 \\
10490 \\
3606\end{array}$ & $\begin{array}{r}15525 \\
12587 \\
2939\end{array}$ \\
\hline \multicolumn{6}{|c|}{ ('000 tons) } \\
\hline Newsprint & $\begin{array}{l}\text { Supply } \\
\text { Demand } \\
\text { Balance }\end{array}$ & $\begin{array}{r}1048 \\
1916 \\
-868\end{array}$ & $\begin{array}{r}1998 \\
2934 \\
-936\end{array}$ & $\begin{array}{r}3000 \\
4341 \\
-1340\end{array}$ & $\begin{array}{r}3585 \\
5305 \\
-1720\end{array}$ \\
\hline Total & $\begin{array}{l}\text { Supply } \\
\text { Demand } \\
\text { Balance }\end{array}$ & $\begin{array}{r}10787 \\
13154 \\
-2367\end{array}$ & $\begin{array}{r}17142 \\
21353 \\
-4211\end{array}$ & $\begin{array}{r}25592 \\
32503 \\
-6911\end{array}$ & $\begin{array}{r}30297 \\
40251 \\
-9954\end{array}$ \\
\hline $\begin{array}{l}\text { Wood } \\
\text { Pulp }\end{array}$ & $\begin{array}{l}\text { Net } \\
\text { Imports }\end{array}$ & 1720 & 2300 & 2970 & 3410 \\
\hline
\end{tabular}

'Balance indicates net trade

Source: ADB 1987 Reconstruction of various tables 
Indonesia can be expected to remain a significant exporter as the others are experiencing log supply problems. ADB forecasts that Indonesia's plywood production will reach 9 million $\mathrm{m}^{3}$ by the year 2000 .

However, even the slower growth rate in this decade will not likely be maintained in the next. The longer-term supply of large dimension quality logs is doubtful; the future timber supply may actually come under greater pressure to satisfy domestic and export sawlog requirements which are expected to grow.

Particle board and fibreboard will unlikely show much movement outside the region with the possible exception of marginal quantities of MDF and OSB.

For paper and paperboard the region is expected to be a net importer, particularly for newsprint, despite a steady improvement in self-sufficiency. The relative role of North and South America (Brazil and Chile) and possibly even New Zealand is difficult to forecast at this stage; however, the possibilities for North America appear to be quite good over the near term.

Printing and writing paper should continue to be in a deficit position over the next two decades, with net imports being supplied from North America, Western Europe and Japan. Imports of industrial paper and board will largely be confined to kraft liner, sack and kraft papers from North America with the lower grades of packaging papers and board produced in the region from hardwood, non-wood pulps and recycled papers.

Chemical pulps have largely been imported from North America in the past and future imports will increasingly come from Brazil and Chile. The most difficult aspect to assess at this point is that where wood supplies suitable for pulp furnish exist in the region, the costs of infrastructure appear to be the limiting factor.

For forest products overall, the main uncertainty is the sustainable supply from the natural forest resource in the early part of the next century and the extent to which industrial plantations can economically substitute for prospective shortfalls from the natural forest.

\section{Regional Supply Trends and Prospects}

The area of closed forest in the region has been estimated to be 401 million hectares or $21 \%$ of the total land area in 1980 (ADB 1987). Productive forest was estimated to be about 280 million hectares or $70 \%$ of the closed natural forest. Additionally, there are about 6 million hectares of bamboo forest which have potential as pulp furnish. Similarly, there are substantial areas of coconut and rubberwood that have potential application for some grades of plywood, structural timber and furniture wood for domestic markets. Most of this resource is currently being used for fuelwood, posts and poles. Malaysia, Indonesia and the Philippines alone have approximately 6 million hectares of rubber plantations while the Philippines and Indonesia have about 5 million hectares of coconut palm plantations.

Nevertheless, the predominate share of future industrial wood supplies will continue to come from the natural forests despite a very rapid increase in supply from industrial plantations. Table 3 gives the forecasted industrial roundwood supplies for the major producing countries from natural and
Table 3. Regional production of industrial Roundwood to 2005

\begin{tabular}{|c|c|c|c|c|c|c|}
\hline \multirow[b]{3}{*}{ Country/Region } & \multicolumn{2}{|c|}{ Natural Forest } & \multicolumn{2}{|c|}{ Plantations } & \multicolumn{2}{|c|}{ Total } \\
\hline & 1982 & 2005 & $\overline{1982}$ & 2005 & 1982 & 2005 \\
\hline & \multicolumn{6}{|c|}{ (millions $\mathrm{m}^{3} /$ year) } \\
\hline India & 13.8 & 25.0 & 2.0 & 8.0 & 15.8 & 33.0 \\
\hline $\begin{array}{l}\text { Philippines and } \\
\text { Malaysia }\end{array}$ & 37.4 & 26.0 & 0.1 & 5.9 & 37.5 & 31.9 \\
\hline Indonesia & 13.2 & 45.0 & 0.4 & 7.0 & 13.6 & 52.0 \\
\hline PRC & 37.3 & 25.4 & 4.0 & 45.0 & 41.3 & 70.4 \\
\hline Rest of region & 13.1 & 20.8 & 0.3 & 9.9 & 13.4 & 30.8 \\
\hline Total & 114.8 & 142.2 & 6.8 & 75.8 & 121.6 & 218.1 \\
\hline
\end{tabular}

Source: ADB 1987

plantation forests to the year 2005 . The critical role that both natural forests in general and Indonesia in particular will play in regional supply in the future is quite evident. This forecast suggests that Indonesia's share of regional supply may increase nearly $21 / 2$ times for timber from natural forests in the period 1982-2005. However, it is difficult to accept this rather optimistic view of increased supply from the natural forest for the following reasons.

The years of peak production in 1978/79 were ones of historically high log prices, significantly easier access and shorter transport distances. In those years, the levels of production were 27.7 and 25.3 million $\mathrm{m}^{3}$ respectively. Even if the level of 45 million $\mathrm{m}^{3}$ were to be attained, it is particularly difficult to accept the sustainability of such a level except for a short time. This is largely due to the unknown aspects of deforestation and depletion noted earlier as well as a loss of productive forest land from encroachment - either for permanent agriculture or shifting cultivation and other land uses.

The regional demand forecasts in Table 2 are contingent upon relatively low cost timber supplies from Indonesia. There is also the strong liklihood that the level of 45 million $\mathrm{m}^{3}$ per year could not be sustained but for a short time. This in turn suggests that a significant increase in real prices for solid wood products in the region and consequent reduction in demand. This situation would only be offset by alternative supplies from other regions.

\section{The Opportunity for Canada}

A recent study by Woodbridge, Reed \& Associates (WRA 1988) for Forestry Canada addresses a number of these changing global conditions for forest products trade. The study concludes that while overall growth prospects are good, the Canadian forest industry must continue to evolve by increasing the productivity in its traditional product mix while developing markets for new products of higher value, largely by building upon our competitive advantages. These advantages are found in our abundance of low-cost energy, a welldeveloped industry structure, proximity to the large (and growing) US market and an extensive forest resource.

The wood products group will still offer many possibilities for growth, albeit in a somewhat different direction. The Pacific Rim countries (except Japan), in particular China, seem to offer the best opportunity for incremental Canadian commodity lumber supply. 
Because reconstituted products tend to substitute technology, energy and capital for labour, the trend will be towards their production and use in the more industrialized countries of the world. Composites can incorporate materials other than wood (e.g. metals, plastics) to meet specific end use demands. Further, composites can be made from species less desirable for traditional wood products and from nonwoody plants, e.g., bamboo (Smith 1986). Plywood production can be expected to decline gradually. Canada's share of global production is expected to remain constant due to capabilities in waferboard/oriented strand board (OSB) and medium density fibreboard.

Most of the increase in global consumption of paper and paperboard will be in the three large markets of North America, Western Europe and Japan, and the U.S. will account for a quarter of the growth in demand. New suppliers will increase resulting in greater competition in the lowerpriced commodity grades. Our comparative advantage lies in highyield mechanical fibre-based grades.

Bleached softwood kraft pulp, the traditional area of our comparative advantage, will remain important but lose some market share to bleached hardwood kraft and mechanical pulps.

The overall characteristic of future forest products production and trade will be a general shift towards a greater number and largely higher quality of products seeking to satisfy increasingly smaller, speciality markets.

\section{Summary}

This brief overview has attempted to capture the flavour of global developments in economic wood supply and demand with particular reference to the Asia-Pacific region as a major participant in production, consumption and trade of forest products. World supplies of industrial wood on a sustainable basis are estimated to be adequate to meet future demand to the year 2000 without real price changes. Newly emerging competitors in the commodity grades and new processes/products will evolve that may significantly alter the pattern of trade in the early part of the next century.

\section{References}

Asian Development Bank. 1987. A Review of Forestry and Forest Industries in the Asia-Pacific Region. Manila.

Arnold, J.E.M. and E.M. Mhzavz. 1985. Forests for People: The Developing Country Case Pap. at 12th Commonw. For. Conf. Victoria, BC.

FAO. 1982. World Forest Products: Demand and Supply, 1990 and 2000 For. Pap. No. 29. Rome.

FAO. 1988. Forest Products: World Outlook Projections Forestry Paper No. 84. Rome.

McGaughey, S. and H. Gregerson 1983. Inter-American Development Bank. Washington, D.C.

Scott, A.D. and P.H. Pearse. 1989. Natural resources in a High-Tech Economy; Scarcity versus resourcefulness FEPA Research Unit. UBC Working Paper 117

Sedjo, R. and K. Lyon. 1986. Long-term Timber Supply: Demand Side Considerations. Pap. at XVIII IUFRO World Congress. Ljubljana, Yugoslavia

Smith, R.V. 1986. Trade in solid wood products - A Canadian perspective. For. Chron. 62: 322-329.

Woodbridge, Reed \& Associates. 1988. Canada's Forest Industry The Next Twenty Years: Prospects \& Priorities. Vols. 1-6. Prepared for Government of Canada, Canadian Forestry Service.

World Bank. 1987. The Forest Industries Sector: An Operational Strategy For Developing Countries. Internal Report. Industry Division. Washington, D.C.

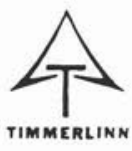

TIMMERLINN LMMTEE

PROFESSIONAL AND TECHNICAL SERVICES

IN FORESTRY AND ENVIRONMENTAL SCIENCES

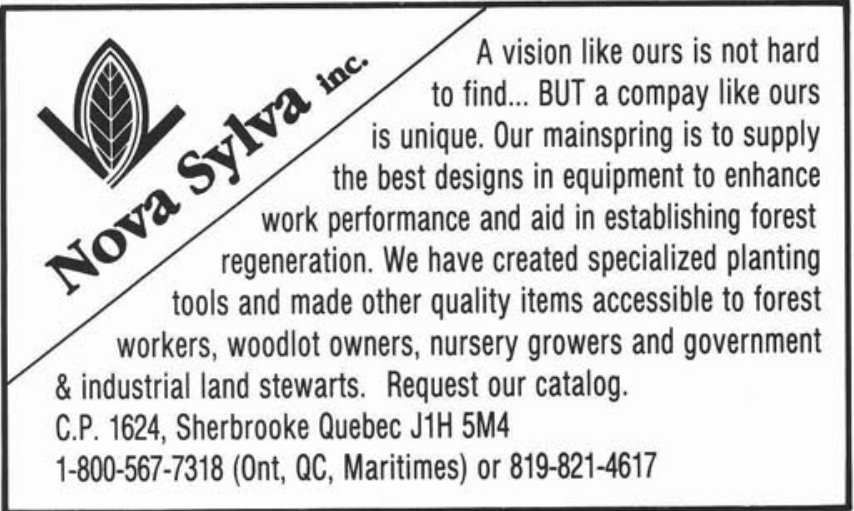

